\title{
References of Part III
}

Andrews, D. G., J. R. Holton, and C. B. Leovy. Middle atmosphere dynamics. Academic Press, 1987.

Baumgarten, G. Doppler Rayleigh/Mie/Raman lidar for wind and temperature measurements in the middle atmosphere up to $80 \mathrm{~km}$. Atmospheric Measurement Techniques, 3, 1509-1518, 2010, DOI: 10.5194/amt-3-1509-2010.

Bernath, P. F., C. T. McElroy, M. C. Abrams, C. D. Boone, M. Butler, et al. Atmospheric Chemistry Experiment (ACE): Mission overview. Geophysical Research Letters, 32, L15S01, 2005, DOI: 10.1029/2005GL022386.

Bony, S., and B. Stevens, I. Held, J. Dufresne, E. K.A., P. Friedlingstein, G. S., and C. Senior. Carbon Dioxide and Climate: Perspectives on a Scientific Assessment, in: G.R. Asrar and J.W. Hurrell (eds.), Climate Science for Serving Society: Research, Modeling and Prediction Priorities. Springer, 2013.

Brasseur, G. P., and S. Solomon. Aeronomy of the Middle Atmosphere: Chemistry and Physics of the Stratosphere and Mesosphere. Springer, 2005.

Bremer, J., and U. Berger. Mesospheric temperature trends derived from groundbased LF phase-height observations at mid-latitudes: comparison with model simulations. Journal of Atmospheric and Solar-Terrestrial Physics, 64, 805-816, 2002, DOI: 10.1016/S1364-6826(02)00073-1.

Brönnimann, S., T. Ewen, T. Griesser, and R. Jenne. Multidecadal Signal of Solar Variability in the Upper Troposphere During the 20th Century. Space Science Reviews, 125(1-4), 305-317, 2007, DOI: 10.1007/s11214-006-9065-2, http: //adslabs.org/adsabs/abs/2006SSRv . 125 . 305B/.

Chiodo, G., D. R. Marsh, R. Garcia-Herrera, N. Calvo, and J. A. García. On the detection of the solar signal in the tropical stratosphere. Atmospheric Chemistry \& Physics, 14, 5251-5269, 2014, DOI: 10.5194/acp-14-5251-2014.

Courant, K., R., F. Friedrichs, and L. H. On the Partial Difference Equations of Mathematical Physics. Mathematische Annalen, 100, 32-74, 1928. Republished 1967.

Crooks, S. A., and L. J. Gray. Characterization of the 11-Year Solar Signal Using a Multiple Regression Analysis of the ERA-40 Dataset. Journal of Climate, 18, 996-1015, 2005, DOI: 10.1175/JCLI-3308.1.

Damadeo, R. P., J. M. Zawodny, L. W. Thomason, and N. Iyer. SAGE version 7.0 algorithm: application to SAGE II. Atmospheric Measurement Techniques, 6, 3539-3561, 2013, DOI: 10.5194/amt-6-3539-2013. 
Dee, D. P., S. M. Uppala, A. J. Simmons, P. Berrisford, P. Poli, et al. The ERAInterim reanalysis: configuration and performance of the data assimilation system. Quarterly Journal of the Royal Meteorological Society, 137(656), 553-597, 2011, DOI: 10.1002/qj.828, http://doi.wiley.com/10.1002/qj.828.

Diamantakis, M., and J. Flemming. Global mass fixer algorithms for conservative tracer transport in the ECMWF model. Geoscientific Model Development, 7, 965979, 2014, DOI: 10.5194/gmd-7-965-2014.

Duchon, C. E., and M. S. O'Malley. Estimating Cloud Type from Pyranometer Observations. Journal of Applied Meteorology, 38, 132-141, 1999, DOI: 10.1175/15200450(1999)038;0132:ECTFPO ¿2.0.CO;2.

Fiedler, J., G. Baumgarten, and F.-J. Lübken. NLC observations during one solar cycle above ALOMAR. Journal of Atmospheric and Solar-Terrestrial Physics, 71, 424-433, 2009, DOI: 10.1016/j.jastp.2008.11.010.

Forster, P. M., V. I. Fomichev, E. Rozanov, C. Cagnazzo, A. I. Jonsson, et al. Evaluation of radiation scheme performance within chemistry climate models. Journal of Geophysical Research (Atmospheres), 116, D10302, 2011, DOI: 10.1029/2010JD015361.

Funke, B., A. Baumgaertner, M. Calisto, T. Egorova, C. H. Jackman, et al. Composition changes after the "Halloween" solar proton event: the High Energy Particle Precipitation in the Atmosphere (HEPPA) model versus MIPAS data intercomparison study. Atmospheric Chemistry $\&$ Physics, 11, 9089-9139, 2011, DOI: $10.5194 /$ acp-11-9089-2011.

Gleisner, H., and P. Thejll. Patterns of tropospheric response to solar variability. grl, 30, 1711, 2003, DOI: 10.1029/2003GL017129.

Gray, L. J., J. Beer, M. Geller, J. D. Haigh, M. Lockwood, et al. Solar Influences on Climate. Reviews of Geophysics, 48, RG4001, 2010, DOI: 10.1029/2009RG000282.

Gray, L. J., J. Beer, M. Geller, J. D. Haigh, M. Lockwood, et al. Correction to Solar influences on climate. Reviews of Geophysics, 50, RG1006, 2012, DOI: $10.1029 / 2011 R G 000387$.

Haigh, J. D. The role of stratospheric ozone in modulating the solar radiative forcing of climate. Nature, 370, 544-546, 1994, DOI: 10.1038/370544a0.

Haigh, J. D., M. Blackburn, and R. Day. The Response of Tropospheric Circulation to Perturbations in Lower-Stratospheric Temperature. Journal of Climate, 18, 3672-3685, 2005, DOI: 10.1175/JCLI3472.1.

Holton, J. R. An introduction to dynamic meteorology. Academic Press, 1992.

Jacobson, M. Fundamentals of atmospheric modeling. Cambridge University Press, 1999. 
Jacobson, M. Z. Fundamentals of Atmospheric Modeling. Cambridge University Press, 2005.

Janowiak, J. E., and P. Xie. CAMS-OPI: A Global Satellite-Rain Gauge Merged Product for Real-Time Precipitation Monitoring Applications. Journal of Climate, 12, 3335-3342, 1999, DOI: 10.1175/1520-0442(1999)012¡3335:COAGSR; 2.0. CO;2.

Kalnay, E., M. Kanamitsu, R. Kistler, W. Collins, D. Deaven, et al. The NCEP/ NCAR 40-year reanalysis project. Bull. Amer. Meteor. Soc., 77, 437-471, 1996.

Keckhut, P., J. D. Wild, M. Gelman, A. J. Miller, and A. Hauchecorne. Investigations on long-term temperature changes in the upper stratosphere using lidar data and NCEP analyses. Journal of Geophysical Research (Atmospheres), 106, 7937-7944, 2001, DOI: 10.1029/2000JD900845.

Lindsay, R., M. Wensnahan, A. Schweiger, and J. Zhang. Evaluation of Seven Different Atmospheric Reanalysis Products in the Arctic*. Journal of Climate, 27, 2588-2606, 2014, DOI: 10.1175/JCLI-D-13-00014.1.

Lübken, F.-J., U. Berger, and G. Baumgarten. Temperature trends in the midlatitude summer mesosphere. Journal of Geophysical Research (Atmospheres), 118, 13,347, 2013, DOI: 10.1002/2013JD020576.

Mayr, H. G., J. G. Mengel, F. T. Huang, and E. R. Nash. Equatorial annual oscillation with QBO-driven 5-year modulation in NCEP data. Annales Geophysicae, 25, 37-45, 2007, DOI: 10.5194/angeo-25-37-2007.

Mayr, H. G., J. G. Mengel, F. T. Huang, and E. R. Nash. Solar cycle signatures in the NCEP equatorial annual oscillation. Annales Geophysicae, 27, 3225-3235, 2009, DOI: 10.5194/angeo-27-3225-2009.

Mc Guffie, K., and A. Henderson-Sellers. A Climate Modelling Primer, 1987.

McLandress, C., D. A. Plummer, and T. G. Shepherd. Technical Note: A simple procedure for removing temporal discontinuities in ERA-Interim upper stratospheric temperatures for use in nudged chemistry-climate model simulations. Atmospheric Chemistry \& Physics, 14, 1547-1555, 2014, DOI: 10.5194/acp-14-15472014.

Mitchell, D. M., L. J. Gray, M. Fujiwara, T. Hibino, J. A. Anstey, et al. Signatures of naturally induced variability in the atmosphere using multiple reanalysis datasets. Quarterly Journal of the Royal Meteorological Society, n/a-n/a, 2014, DOI: 10.1002/qj.2492, http://dx.doi.org/10.1002/qj . 2492.

Mlynczak, M. G., B. T. Marshall, F. J. Martin-Torres, J. M. Russell, R. E. Thompson, E. E. Remsberg, and L. L. Gordley. Sounding of the Atmosphere using Broadband Emission Radiometry observations of daytime mesospheric $\mathrm{O}_{2}\left({ }^{1} \Delta\right) 1.27 \mu \mathrm{m}$ 
emission and derivation of ozone, atomic oxygen, and solar and chemical energy deposition rates. Journal of Geophysical Research (Atmospheres), 112, D15306, 2007, DOI: 10.1029/2006JD008355.

Moberg, A., D. M. Sonechkin, K. Holmgren, N. M. Datsenko, and W. Karlén. Highly variable Northern Hemisphere temperatures reconstructed from low- and high-resolution proxy data. Nature, 433, 613-617, 2005, DOI: $10.1038 /$ nature03265.

Mote, P., and A. O'Neill. Numerical Modeling of the Global Atmosphere in the Climate System, Series C: Mathematical and Physical Sciences, Vol. 550. Kluwer Academic Publisher, 1998. ISBM 0-7923-6301-9 (HB) 0-7923-6302-7 (PB).

Murtagh, D., U. Frisk, F. Merino, M. Ridal, A. Jonsson, et al. Review: An overview of the Odin atmospheric mission. Canadian Journal of Physics, 80, 309, 2002, DOI: $110.1139 / \mathrm{p} 01-157$.

Nissen, K. M., K. Matthes, U. Langematz, and B. Mayer. Towards a better representation of the solar cycle in general circulation models. Atmospheric Chemistry \&5 Physics, 7, 5391-5400, 2007.

Offermann, D., P. Hoffmann, P. Knieling, R. Koppmann, J. Oberheide, and W. Steinbrecht. Long-term trends and solar cycle variations of mesospheric temperature and dynamics. Journal of Geophysical Research (Atmospheres), 115, D18127, 2010, DOI: 10.1029/2009JD013363.

Onogi, K., J. Tsutsui, and H. Koide. The JRA-25 reanalysis. Journal of Meteorological Society, 85(3), 369-432, 2007. http://ecco2.jpl.nasa.gov/data2/ data/atmos/jra25/Onogi_2007_JRA25.pdf.

Østvand, L., T. Nilsen, K. Rypdal, D. Divine, and M. Rypdal. Long-range memory in internal and forced dynamics of millennium-long climate model simulations. Earth System Dynamics, 5, 295-308, 2014, DOI: 10.5194/esd-5-295-2014.

Peixoto, J., and A. Oort. Physics of climate. American Institute of Physics, 1992.

Rodger, C. J., J. B. Brundell, R. H. Holzworth, and E. H. Lay. Growing Detection Efficiency of the World Wide Lightning Location Network. In: American Institute of Physics Conference Series, vol. 1118 of American Institute of Physics Conference Series, 15-20, 2009, DOI: 10.1063/1.3137706.

Rodgers, C. D. Inverse Methods for Atmospheric Sounding: Theory and Practice, vol. 2 of Series on Atmospheric, Oceanic and Planetary Physics, F. W. Taylor, ed. World Scientific Publishing Co. Pte. Ltd, Singapore, 2000.

Saha, S., S. Moorthi, H.-L. Pan, X. Wu, J. Wang, et al. The NCEP Climate Forecast System Reanalysis. Bulletin of the American Meteorological Society, 91(8), 1015-1057, 2010, DOI: 10.1175/2010BAMS3001.1, http://journals.ametsoc. org/doi/abs/10.1175/2010BAMS3001.1. 
Schneider, S. Introduction to climate modeling, Chapter 1 in Climate system modeling. Cambridge University Press, 1992.

Solanki, S. K., I. G. Usoskin, B. Kromer, M. Schüssler, and J. Beer. Unusual activity of the Sun during recent decades compared to the previous 11,000 years. Nature, 431, 1084-1087, 2004.

Soon, W., K. Dutta, D. R. Legates, V. Velasco, and W. Zhang. Variation in surface air temperature of China during the 20th century. Journal of Atmospheric and Solar-Terrestrial Physics, 73, 2331-2344, 2011, DOI: 10.1016/j.jastp.2011.07.007.

Steinhilber, F., J. Beer, and C. Fröhlich. Total solar irradiance during the Holocene. Geophysical Research Letters, 36 (L19704), 2009, DOI: $10.1029 / 2009$ GL040142.

Stocker, T. Introduction to Climate Modelling. Springer, 2011.

Stocker, T., D. Qin, G.-K. Plattner, M. Tignor, S. Allen, J. Boschung, A. Nauels, Y. Xia, V. Bex, and P. Midgley. IPCC, 2014: Climate Change 2013: The physical science basis. Contribution of Working Group 1 to the Fifth Assessment Report of the Intergovernmental Panel on Climate Change. Cambridge University Press, 2013.

Toohey, M., M. I. Hegglin, S. Tegtmeier, J. Anderson, J. A. Añel, et al. Characterizing sampling biases in the trace gas climatologies of the SPARC Data Initiative. Journal of Geophysical Research (Atmospheres), 118, 11,847, 2013, DOI: $10.1002 /$ jgrd.50874.

Trenberth, K. Climate System Modeling. Cambridge University Press, ISBN 0-521-43231-6 (HB), 1992.

Uppala, S. M., P. W. Kållberg, A. J. Simmons, U. Andrae, V. D. C. Bechtold, et al. The ERA-40 re-analysis. Quarterly Journal of the Royal Meteorological Society, 131, 2961-3012, 2005, DOI: 10.1256/qj.04.176.

van Loon, H., G. A. Meehl, and D. J. Shea. Coupled air-sea response to solar forcing in the Pacific region during northern winter. Journal of Geophysical Research (Atmospheres), 112, D02108, 2007, DOI: 10.1029/2006JD007378.

Washington, W., and C. Parkinson. An Introduction to Three-dimensional Climate Modelling. Oxford University Press, Oxford, 1986. ISBN 0.935702-52-0.

Waters, J. W., L. Froidevaux, R. S. Harwood, R. F. Jarnot, H. M. Pickett, et al. The Earth Observing System Microwave Limb Sounder (EOS MLS) on the Aura Satellite. IEEE Transactions on Geoscience and Remote Sensing, 44, 1075-1092, 2006, DOI: 10.1109/TGRS.2006.873771.

WMO. Guide to Meteorological Instruments and Methods of Observation. Tech. Rep. 8, World Meteorological Organisation, Geneva, 1988. 
